\title{
PUBLIC SPEAKING DALAM KONTEKS PENGAJARAN
}

\author{
Grace Swestin $^{1 *}$; Kartika Bayu Primasanti ${ }^{1}$ \\ Program Studi Ilmu Komunikasi, Fakultasa Ilmu Komunikasi, Universitas Kristen Petra \\ Jalan Siwalankerto 121-131, Surabaya 60236, INDONESIA \\ * Korespondensi penulis, e-mail: grace.swestin@gmail.com
}

\begin{abstract}
ABSTRAK
Literatur yang ada tentang public speaking, khususnya yang berbahasa Indonesia, pada umumnya berfokus pada kiat-kiat praktis. Rujukan-rujukan yang ada kerap berasumsi bahwa ada sebuah rumus universal yang dapat diterapkan dalam berbicara di depan public. Artikel ini memaparkan bahwa public speaking seharusnya dikaji dan dipelajari dalam konteks yang partikular. Dalam artikel ini, peneliti memfokuskan pada konsep public speaking dalam konteks pengajaran. Berbicara di depan publik merupakan bagian tidak terpisahkan dari tradisi akademik. Oleh karena itu, peneliti melakukan kajian pustaka untuk menelusuri kaitan antara konsep public speaking dengan pengajaran dengan menjabarkan bagaimana peran sentral guru atau pengajar sebagai pembicara dan murid atau peserta didik sebagai audiensnya.
\end{abstract}

Kata kunci: Public speaking; pengajaran; guru; pengajar; murid; peserta didik; audiens.

\begin{abstract}
Literatures on public speaking, particularly those in the Indonesian language, often focus on explaining know-hows as well as assuming that public speaking has a universal formula which speakers can abide by. This article argues that public speaking should be studied in particular contexts. It further focuses on the concept of public speaking in a teaching and learning environment. Bearing in mind that public speaking is an indispensable part of academic tradition; this articlesthrough literature research - attempts to go beyond a practical-centric approach and reviews the connection between the concepts of public speaking and teaching by expounding on the central roles that teacher and student play as speaker and audience.
\end{abstract}

Keywords: Public speaking; teaching; teacher; student; speaker; audience.

\section{PENDAhUluan}

Konsep klasik retorika dipahami sebagai hanya teori dan secara aksiologi bernilai pada konteks-konteks tertentu saja. Misalnya untuk memenangkan sidang di pengadilan, membela diri, atau mempengaruhi publik dengan berbagai rumusnya. Observasi peneliti yang adalah pengajar di tingkat perguruan tinggi serta pengalaman menjadi trainer dalam pelatihan public speaking menunjukkan adanya kebutuhan akan untuk memahami dasar-dasar berbicara di depan umum lebih dari sekedar pemahaman praktis bersifat know how. Referensi-referensi-khususnya dalam literatur berbahasa Indonesia - berorientasi praktis terhadap public speaking, yakni untuk sekadar belajar teknikteknik berbicara di depan umum atau bagaimana menggunakan alat presentasi yang mumpuni, atau bagaimana mengurangi segala hambatan dalam berbicara di depan umum. Padahal, lebih dari sekadar praktik, public speaking membutuhkan pendalaman secara konseptual agar dapat menampilkan ide, melalui isi pesan dan performa di depan khalayak sesuai setting yang dihadapi.
Pentingnya memahami kembali konsep dasar public speaking tidak lain karena public speaking bersifat kontekstual. Dengan kata lain, sebenarnya tidak ada rumus untuk public speaking yang dapat diterapkan secara universal. Bertolak dari pemikiran tersebut, peneliti terdorong untuk melakukan studi pustaka guna menyusuri kembali konsep public speaking yang komprehensif dalam konteks pengajaran.

Tidak dapat dipungkiri bahwa dalam institusi pendidikan, ceramah masih menjadi metode yang kerap digunakan. Dalam pendidikan tinggi, misalnya, bahkan istilah "kuliah" menyiratkan sistem ceramah yang dilakukan dosen terhadap mahasiswa dalam kelas. Dengan munculnya istilah-istilah seperti kurikulum berbasis kompetensi student-based learning, problembased learning, dan experiential learning, banyak pihak telah menyimpulkan bahwa mengajar dengan cara ceramah merupakan praktik usang dan tidak efektif.

Website Oxford Brookes University, Inggris bahkan mereproduksi tulisan Gibbs (1981) yang berjudul 
"Twenty terrible reasons for lecturing" (Dua Puluh Alasan Mengapa Berceramah Itu Buruk). Gibbs mengkritik ceramah sebagai cara yang tidak dapat membantu peserta didik untuk mencapai tujuan pembelajaran. Menurutnya, ketergantungan pada ceramah, khususnya dalam konteks pengajaran pada pendidikan tinggi, tidak dapat memberikan pengalaman yang cukup bermakan bagi peserta didik untuk memahami materi yang diajarkan.

Meskipun demikian, Gibbs tidak memungkiri bahwa mustahil bila ceramah (lecture) dihapuskan dari proses pengajaran. Tujuannya dalam menuliskan artikel tersebut adalah untuk mengkritik kondisi di mana, menurutnya, terlalu banyak pengajar bergantung pada metode ceramah. Ceramah mendominasi proses belajar mengajar pada pendidikan tinggi dan sebagian besar pengajar berceramah bukan karena efektivitas dalam mencapai tujuan edukatif, namun karena faktor-faktor lain mulai dari ketidak pedulian terhadap peserta didik, sikap pengajar yang terbiasa mentransmisikan pengetahuan secara top down hingga keterbatasan-keterbatasan insititusional (misalnya beban pekerjaan guru yang terlalu tinggi, keterbatasan waktu dan tidak adanya keterampilan untuk menyusun rencana pengajaran).

Alasan-alasan demikianlah yang membuat ceramah (lecture) sebagai metode yang dipandang kurang bermanfaat bagi siswa atau mahasiswa. Walaupun metode ceramah tidak disarankan sebagai metode utama, Gibbs menyatakan bahwa ceramah tetap merupakan bagian yang tidak terpisahkan dalam pengajaran. Dalam kesimpulan penelitiannya, Gibbs sendiri menuliskan:

I would not like to leave the impression that I feel that there is no justification for ever lecturing. I lecture myself (though seldom for more than fifteen minutes at a stretch and then seldom when written substitutes are available). I believe there are circumstances when a well structured, well paced, varied, lively lecture can be the most efficient teaching method (Gibbs, 1981).

(Saya tidak ingin memberikan kesan bahwa saya merasa ceramah sama sekali tidak dapat dibenarkan. Saya sendiri berceramah (meskipun jarang lebih dari lima belas menit dan bila ada materi tertulis yang dapat dibaca oleh siswa, saya jarang berceramah). Saya percaya bahwa ada situasi di mana sebuah ceramah yang terstruktur dengan baik, dengan ritme tertata, bervariasi dan hidup dapat menjadi metode pengajaran yang paling efisien)
Dalam metode ceramah, otoritas yang dimiliki oleh pengajar dalam kelas bergantung pada pengetahuan dalam bidang dan topik yang diajarkan serta pada kondisi belajar mengajar secara tatap muka. Ini adalah bentuk otoritas pengajar dari sudut pandang konservatif. Semakin hari, otoritas semacam ini semakin dipertanyakan karena keterbatasan-keterbatasan yang kerap dialami baik oleh pengajar yang berceramah maupun oleh siswa yang mendengarkan; termasuk di dalamnya rentang perhatian siswa semakin pendek, jumlah peserta didik yang terlalu banyak, suara pengajar yang tidak memadai, cara mencatat yang seringkali tidak efektif, serta kurangnya interaksi dengan siswa dan terbatasnya ruang untuk memberikan umpan balik. Dengan kekurangan-kekurangan tersebut tidak heran bila ceramah sebagai sebuah metode yang dipraktikkan oleh begitu banyak pengajar hingga saat ini sulit dipercaya.

Hal ini disebabkan karena metode ini terlalu sering dilakukan tanpa menghiraukan peran peserta didik sebagai audiens yang perlu berinteraksi dan terlibattidak hanya mendengarkan, mencatat, dan menirukan - untuk mencapai tingkat pemahaman yang baik. Ini terkait dengan konsep pengajaran yang lebih dari sekedar transmisi pengetahuan, pengajaran ditujukan untuk membina pola pikir dan harus dapat menstimulasi peserta didik untuk melakukan pembelajaran mandiri.

Bahkan metode pengajaran yang berfokus pada pendekatan student-centered sekalipun, tidak dapat terlepas dari peran guru dalam mengendalikan proses belajar mengajar, khususnya dalam kelas. Sebagai contoh, beberapa teknik pengajaran terhadap anak kecil yang disampaikan oleh MacNaughton dan Williams (2004), meski tidak ada yang mengindikasikan metode ceramah, sangat bersinggungan dengan keterampilan public speaking. Teknik-teknik yang dijelaskan MacNaughton dan Williams antara lain memperagakan (demonstrating), menggambarkan (describing), memfasilitasi (facilitating), feedback (umpan balik), mendengarkan (listening), memperagakan dengan menirukan (modelling), memberitahu dan menginstruksikan (telling and instructing). Dalam mempratekkan metode-metode pengajaran tersebut, tentunya guru sebagai harus benar-benar mengetahui posisinya sebagai seorang pembicara. Ia pun harus mampu mengendalikan proses komunikasi yang terjalin antara dirinya dengan peserta didiknya agar mencapai tujuan pembelajaran yang disasar. Berdasar pada pemikiran-pemikiran tersebutlah, basis pengetahuan teoritis maupun keterampilan public speaking pada seorang pengajar sangatlah esensial. 
Beberapa penelitian yang berkaitan dengan public speaking dan pendidikan telah dilakukan sebelumnya. Rivera (2011) telah meneliti bahwa public speaking sendiri menjadi subyek yang penting dalam pelajaran di tingkat sekolah menengah. Dari penelitian ini diketahui bahwa persiapan formal para siswa untuk praktik public speaking sangat menentukan kualitas kelulusan mereka. Pan dan Yan (2010) juga telah mengkaji sebuah metode public speaking education untuk diterapkan di dalam kelas-kelas. Hasil riset para peneliti ini menunjukkan bahwa penggunaan metode public speaking tertentu sangat mempengaruhi performa para siswa di kelas. Dari perspektif teknologi media baru, Clark dan Jones (2001) mengkaji penggunaan media online dan media tradisional untuk mengajar public speaking. Beberapa penelitian ini bermuara pada pengembangan public speaking dalam konteks pendidikan. Dengan demikian, perlu ada kajian yang menjadi referensi untuk merunut akar public speaking tersebut dalam konteks pendidikan. Penelitian ini akan menjawab gap yang ada.

Oleh karenanya, peneliti bermaksud mengurai konsep public speaking dari sudut pandang komunikator dan komunikannya dalam konteks pengajaran. Mengapa konteks pengajaran menjadi penting untuk mengkaji public speaking? Pertama karena inspirasi bagi seorang public speaker dimulai dari ranah pendidikan, yakni guru/ pendidik/pengajar. Kedua, ranah akademik menjadi setting yang baik untuk mengembangkan kajian-kajian mengenai public speaking. Dalam pembahasan kajian pustaka ini, peneliti akan menguraikan dua aspek penting dalam public speaking, yakni audiens dan speaker dalam perspektif pengajaran.

\section{PEMBAHASAN}

\subsection{Siswa Sebagai Audiens Public Speaking}

Sejak diundangkannya Undang-Undang Sisdiknas No. 20/2003, sistem pendidikan nasional di Indonesia mulai menerapkan pendidikan yang berpusat pada siswa. Yang dimaksud dengan pendidikan adalah usaha sadar dan terencana mewujudkan suasana belajar dan proses pembelajaran agar peserta didik secara aktif mengembangkan potensinya sendiri. Pengertian ini merupakan perwujudan perubahan mendasar dari pengajaran menjadi pembelajaran pada UU Sisdiknas Np 20/2003. Istilah pengajaran mewakili dominasi guru sebagai pengajar; sedangkan pembelajaran menunjuk peranan siswa aktif sekaligus mengoreksi peranan dominan guru (Dananjaya, 2010, p. 25).
Pembelajaran berpusat pada siswa bersifat strategis dan inovatif. Strategis karena memfasilitasi siswa aktif dalam proses pembelajaran yang mengembangkan potensi dirinya, dan menempatkan siswa atau peserta didik sebagai subyek yang bertanggung jawab atas proses pembelajaran. Inovatif, karena siswa tidak terikat oleh kelas belajar. Guru sebagai sumber dan penentu tujuan tetapi mewujudkan prinsip "manusia memproduksi dirinya sendiri dalam pengalaman realitas sosial" sehingga siswa mempunyai proses pengalaman untuk belajar bagaimana cara belajar yang akan menjadi pedoman belajar sepanjang hayat (Dananjaya, 2010, pp. 26-27).

Di dalam perspektif siswa sebagai pusat pembelajaran ini, terdapat beberapa model yang dapat digunakan, misalnya: model diskusi, model proyek, model permainan, model ice breaker. Model diskusi mensyaratkan keaktifan siswa dalam berbicara atau menulis, serta mengkomunikasikan buah pikiran secara interaktif dengan sesama siswa dan guru. Diskusi ini bisa berupa obrolan pagi (morning talk), diskusi berpasangan, diskusi tentang pemahaman teks, studi kasus, diskusi dengan film, mind mapping, brain storming, serta debat. Model proyek adalah melaksanakan tugas melalui serangkaian aktivitas, misalnya mengamati, membuat prediksi, merencanakan kegiatan pengujian, mengintepretasi, menysusun kesimpulan, lalu mempresentasikannya. Walaupun tampaknya beberapa model yang dianjurkan dalam pembelajaran yang berpusat kepada siswa mengurangi dominasi guru di kelas, namun tetap kegiatan belajar tidak akan lepas dari kemampuan seorang guru untuk berbicara di depan audiensnya, yakni para siswa. Justru, di dalam konteks pembelajaran berpusat pada siswa ini, kemampuan guru untuk menjadi speaker yang menginspirasi sangat penting untuk dipraktikkan sehingga menumbuhkan prakarsa, kreativitas, dan kemandirian siswa.

Jika dilihat dari perspektif an audience-centered speechmaking approach, maka audiens memiliki posisi yang sangat penting dalam kegiatan public speaking. Begitu juga di dalam konteks pembelajaran yang berpusat pada siswa ini, seorang guru yang mengambil bagian sebagai speaker harus menempatkan siswa atau audiens-nya dengan benar. Selama ini, jika penelitian menunjukkan kegagalan proses belajar mengajar di kelas (Kesuma, et al, 2010) salah satunya dikarenakan kurang mampunya seorang guru menempatkan siswanya sebagai audiens.

Dalam audience-centered speechmaking, Beebe dan Beebe (2009, p. 21) mengatakan "as a public 
speaker, you will learn to adapt to your audience based on who your listeners are, their expectations for your speech, and their actions to what you are saying”. Menurut perspektif ini, dalam konteks pembelajaran, seorang guru harus benar-benar mengenal audiensnya, yakni siswa, serta apa harapan mereka melalui pelajaran yang disampaikan. Lebih lanjut, Beebe dan Beebe (2010) menyatakan bahwa the audience is the most important component in the communication process. Hal ini benar jika ditinjau dari persepektif audience-centered approach.

Namun dalam praktiknya, menjadikan audiens penting dalam proses pembelajaran tidaklah mudah. Dominasi guru dengan anggapan bahwa pengetahuannya lebih banyak dan lebih berkuasa di kelas, terkadang menegasikan argumen Beebe mengenai pentingnya murid sebagai audiens. Dalam berbagai kegiatan pembelajaran atau pelatihan, acapkali guru atau pelatih justru lebih menonjolkan kemampuannya dan beragam metode yang menarik tanpa memedulikan apakah hal tersebut sesuai dengan audiensnya. Akhirnya, seperti studi yang dilakukan oleh Rahayasa Research and Training (2010, p. 4), proses pembelajaran yang demikian hanya menghasilkan siswa yang menerima pengetahuan; bukan membangun sendiri pengetahuannya secara kontekstual.

Beebe dan Beebe (2010, p. 21) juga mengatakan bahwa "the decoding of speaker's message depends on the reviewer's or listener's, particular blend of past experiences, attitudes, believe and value" (pengawasandian pesan yang disampaikan oleh seorang pembicara bergantung pada pengalaman masa lalu, sikap, keyakinan dan nilai-nilai yang dipegang oleh pendengarnya). Di dalam proses belajar mengajar, karena pemahaman materi pengajaran sebagai pesan ditentukan oleh latar belakang siswa sebagai audiens, maka guru sebagai speaker perlu melakukan riset audiens untuk mengetahui karakter siswa sebagai audiens.

Riset mengenai siswa sebagai audiens ini dapat dilakukan dalam tiga tahap. Tahap pertama, adalah melakukan riset sebelum kelas dimulai. Riset ini bisa dilakukan dengan mengamati data siswa, berkaitan dengan latar belakang keluarga, suku, usia, catatan akademik, dan data lain yang didokumentasikan. Setelah itu, guru dapat melakukan wawancara dengan guru di kelas sebelumnya atau guru lain yang pernah mengajar siswa di kelas tersebut. Hal-hal yang perlu diketahui adalah keunikan dari individu-individu tertentu serta keunikan kelas secara keseluruhan. Setelah itu, dapat dibuat catatan mengenai karakter individu maupun kelas. Hal ini berguna untuk melakukan pengenalan awal mengenai siapa audiens dari public speaking yang akan dilakukan di dalam kelas.

Pengalaman peneliti menunjukkan, data secara administratif, selengkap apa pun seringkali tidak sama dengan yang ditemui di lapangan. Diperlukan riset tahap ke dua yang peneliti sebut sebagai riset simultan. Riset audiens secara simultan ini dilakukan sembari berada di kelas. Saat berada di depan para siswa ataupun peserta seminar, speaker harus melakukan pengamatan dan wawancara secara simultan. Misalnya, ketika memperkenalkan diri sebagai guru kelas yang baru, guru juga mengenal siswanya satu per satu. Atau saat menerangkan suatu bab, misalnya tentang kedisiplinan, guru dapat menyebut nama seorang siswa dan memintanya memberi testimony tentang dirinya mengenai kedisiplinan. Dengan demikian, guru semakin mengenal siapa audiensnya. Begitu juga dalam pelatihanpelatihan, fasilitator baiknya mengadakan interview spontan terhadap audiensnya.

Tahap ke tiga yang perlu dilakukan sebagai riset audiens adalah mengevaluasi bagaimana keterikutan siswa di dalam kelas selama kelas tersebut berlangsung. Hal ini dapat digunakan sebagai masukkan bagi kelas selanjutnya. Beberapa karakter penting yang harus didapat dari riset audiens ini adalah; diversitas (budaya, nilai-nilai, interest, latar belakang keluarga), level pendidikan, pengalaman individu, tren (fashion, film, gadget). Dengan memahami karakter kelas, audiens akan menjadi pusat yang penting untuk seorang guru sebagai speaker memandang audiens sebagai bagian yang penting dan utama serta memfasilitasi pembelajaran di kelas dengan tepat.

Mengenali noise atau gangguan komunikasi baik secara internal (dalam diri guru sebagai speaker) maupun eksternal (lingkungan, ruangan kelas, microphone, computer, dll) yang mengganggu audiens adalah sangat penting untuk diperhatikan. Seringkali, apa yang dianggap biasa oleh pembicara bisa menjadi noise bagi audiens. Misalnya, cara bicara seorang guru yang terbata-bata dan banyak mengandung ho hum, seperti "ee..." atau "hmm..." bisa saja menjadi gangguan bagi murid yang mendengarkan. Guru perlu melakukan proses evaluasi baik sendiri maupun meminta murid-murid melakukannya. Misalnya mencatat beberapa gangguan, baik internal maupaun eksternal yang dapat mengganggu mereka saat menerima pelajaran. 


\subsection{Guru Sebagai Public Speaker}

Dalam memahami fungsi pengajar sebagai seorang pembicara peneliti mengkaitkan beberapa teori terkait metode dan gaya mengajar dalam teori pengajaran dengan model penyampaian pesan dari pembicara kepada audiens dalam teori public speaking.

\subsubsection{Mengajar: Metode vs. Gaya Pengajaran}

Jarvis (2006) mengungkapkan bahwa metode pengajaran dapat dibedakan dari gaya mengajar. Istilah metode mengajar mengasumsikan bahwa pengajaran adalah teknik atau ilmu yang dapat dipelajari; sementara istilah gaya mengajar mengasumsikan bahwa mengajar lebih merupakan sebuah seni. Jarvis berpendapat bahwa meskipun penting bagi seorang guru untuk mempelajari dan mempraktekkan metode mengajar, gaya mengajar lebih berpengaruh terhadap proses pembelajaran yang terjadi.

Metode mengajar berfokus pada teknik-teknik yang digunakan oleh guru. Metode mengacu pada caracara, proses dan teknik. Dalam pendekatan yang memperlakukan pengajaran sebagai sebuah ilmu, pengajaran secara esensial adalah transmisi pengetahuan atau teori yang melibatkan seorang guru mengajarkan sebuah keahlian kepada peserta didik. Dari sudut pandang ini, pengajaran adalah sebuah kegiatan yang instrumental dan rasional. Hasil akhirnya dapat diukur dan teknik-teknik yang dipergunakan. Metode dapat dapat dievaluasi efektivitasnya secara empiris kuantitatif.

Pendekatan ini kerap digunakan dan ditekankan dalam teori pengajaran di Amerika. Beberapa penelitian menunjukkan bahwa pengajaran memiliki basis yang sepenuhnya rasional dan bentuk-bentuk pengajaran harus dibuat dengan dasar yang rasional tersebut. Sistem harus dibentuk di mana guru dimampukan untuk mempertimbangkan sebanyak mungkin kemungkinan dalam rencana pengajaran mereka. Semua guru diwajibkan untuk mempersiapkan pelajaran dengan teliti dengan menyusun sebuah sistem. Teori yang memperlakukan pengajaran sebagai teknik meyakini bahwa persiapan yang benar dapat menghasilkan hasil atau keluaran yang diharapkan.

Dalam pendekatan ini, model untuk mendesain cara mengajar sangat terperinci dengan teknik-teknik yang mutakhir. Desain ini terdiri dari langkah-langkah dan proses yang harus diimplementasikan oleh seorang pengajar untuk membuat proses belajar mengajar lebih efektif. Jelaslah bahwa yang dipentingkan di sini adalah teknik dan bukan individu guru itu sendiri. Aspek persona seorang guru diposisikan sebagai aspek yang sekunder. Skinner (1968) meyakini hal ini dengan menganalogikan pengajaran sebagai sebuah mesin (teaching machine). Mesin pengajaran itu merupakan sebuah alat (device) untuk mengkontrol kejadian-kejadian yang mungkin terjadi dalam proses belajar mengajar.

Pendekatan yang mementingkan penggunaan berbagai metode pengajaran sangat penting untuk seorang pengajar profesional. Seorang guru yang tidak mempergunakan metode pengajaran bervariasi dan tidak mengevaluasi kesuksesan metode pengajaran mereka adalah guru yang tidak profesional. Walaupun demikian, tidak dapat dipungkiri bahwa dua orang guru, meski menggunakan teknik yang sama dan mengajarkan konten yang sama akan menghasilkan tetap akan melakukannya dengan gaya yang berbeda dan menghasilkan output berbeda. Peserta didik pun acap kali menilai pengajar dari cara pembawaan mereka dan kepribadian yang mereka tampilkan pada saat proses belajar mengajar berlangsung. Ini membuktikan bahwa ada faktor signifikan lain selain teknik atau metode pengajaran. Faktor tersebut "gaya mengajar" (Jarvis, 2006).

"Gaya mengajar" mengacu pada cara mengekspresikan, bukan hanya pada langkah-langkah yang harus dipraktekkan. Oleh Conti (1990, p. 80), istilah gaya (style) dalam konteks ini didefinisikan sebagai "kualitas unik" yang ditunjukkan oleh seorang pengajar. Jarvis (2006) menyatakan bahwa gaya mengajar dapat menjadi penentu bagi "ethos" atau budaya dalam situasi di mana proses pengajaran berlangsung.

Sebuah penelitian yang dilakukan oleh Morrison dan McIntyre (1973) menyimpulkan bahwa tidak ada korelasi yang kuat antara jenis kepribadian (ditentukan melalui tes tipe kepribadian) dengan pendekatan atau metode yang digunakan seorang guru dalam mengajar. Apa pun tipe kepribadian seorang guru, mengajar, pada intinya, bertujuan membantu peserta didik untuk belajar. Untuk melakukan itu, peran guru secara humanistik sebagai seorang individu sangat penting. Dalam menjalankan perannya, guru juga perlu mengadopsi perspektif bahwa terdapat unsur seni dalam mengajar. Pendekatan yang menyatakan pengajaran sebagai sebuah metode tidak berdiri sendiri, tetapi berlangsung sejalan dengan gaya (style) yang dimiliki oleh seorang pengajar dalam menjalankan metode tersebut. 
Davies (1971) menyebutkan bahwa guru tak ubahnya seorang manajer yang mengatur jalannya proses belajar mengajar dalam kelas. Beberapa studi tentang manajemen membuktikan pengaruh gaya kepemimpinan terhadap kondisi pegawai. Salah satunya adalah Teori X dan Teori Y McGregor (1960). Teori $\mathrm{X}$ menyatakan bahwa para manajer berasumsi pekerja pada dasarnya tidak menyukai pekerjaan mereka sehingga mereka harus dikontrol, didisiplinkan dan diarahkan agar mereka tetap bekerja untuk memperoleh hasil yang ditargetkan. Teori Y menekankan bahwa manajer dapat berfokus pada sisi manusiawi dari para pekerja dan berusaha untuk mengembangkan mereka sebagai manusia. Teori manajemen McGregor ini juga sangat relevan dengan dunia pengajaran.

Sebuah studi lain tentang gaya kepemimpinan dilakukan oleh Lippitt dan White (1958). Mereka meneliti gaya kepemimpinan ditunjukkan oleh sekelompok pemimpin muda. Riset tersebut menemukan tiga kategori, yaitu pemimpin otoriter, laissez-faire, dan demokratis. Pemimpin otoriter menghasilkan ketergantungan anggota kelompok terhadap pemimpinnya. Ketika mereka tidak ada, maka pekerjaan tidak terselesaikan sebagaimana mestinya. Sebaliknya, pada pemimpin laissez- faire, hanya sedikit pekerjaan yang terselesaikan ketika mereka hadir. Sementara pemimpin demokratis menciptakan kohesi dalam kelompok dan kondisi kerja yang harmonis baik pada saat mereka hadir maupun tidak.

Hasil penelitian dalam bidang manajemen ini ini konsisten dengan apa yang ditemukan oleh Galton et al. (1980) tentang cara guru mengendalikan kelas. Vygotsky (1978) juga menemukan bahwa gaya mengajar, selain metode, sangat penting bagi berkembangnya pengertian anak didik. Ia menyimpulkan bahwa anak-anak mencapai pemahaman bukan hanya dari interaksi mereka dengan dunia fisik di sekitar mereka saja. Ada faktor lain yang mempengaruhi bagaimana mereka menerima pengetahuan dan keterampilan yang diajarkan pada mereka. Gaya mengajar seorang guru dalam berinteraksi dengan mereka sangat menentukan berkembangnya pemahaman peserta didik.

Bagi Apps (1991), gaya mengajar merupakan kombinasi antara metode dan konten yang disajikan. Bagi Eble (1998), gaya muncul dari karakter seorang guru. Karakter guru memainkan peranan penting dalam proses pengajaran, karena guru notabene adalah "alat bantu" terpenting bagi peserta didik. Para teoris yang menekankan pada pentingnya metode berpendapat bahwa pengajaran dapat distandarisasikan. Mereka melupakan bahwa sebenarnya gaya mengajar memberi kontribusi besar terhadap proses pembelajaran.

Gaya mengajar menyangkut individualitas masingmasing pengajar dan meyakini bahwa setiap pengajar dan setiap sesi dalam proses pengajaran tidak dapat disamakan. Mengajar tidak dapat semata-mata disamakan dengan proses mekanis karena ada unsur keunikan tersendiri. Merujuk pada Brookfield (2006) dengan menggunakan metode yang secara rasional sangat mutakhir sekalipun, pengajaran dalam kelas tetap dipenuhi dengan kondisi-kondisi yang tidak dapat diprediksi.

Pendekatan yang meyakini mengajar adalah seni sekaligus ilmu meyakini bahwa guru harus mengembangkan karakter secara individu untuk membentuk gaya mengajar yang efektif. Senada dengan itu, Parker (1998) menjelaskan - berdasarkan pengalamannya sebagai guru - pentingnya gaya mengajar yang berasal dari karakter seorang guru. Pada salah satu bab berjudul Teaching Beyond Technique (Mengajar Lebih dari Sekedar Teknik) dalam bukunya Courage to Teach ia menulis sebagai berikut:

After three decades of trying to learn my craft, every class comes down to this: my students and I, face to face, engaged in an ancient and exacting exchange called education. The techniques I have mastered do not disappear but neither do they suffice. Face to face with my students, only one resource is at my immediate command: my identity, my selfhood, my sense of this 'I'who teaches - without which I have no sense of the 'Thou' who learns ......... good teaching cannot be reduced to technique; good teaching comes from the identity and integrity of the teacher (1998, p. 10, italics in original)

(Setelah tiga dasawarsa mempelajari pekerjaan saya, inti dari setiap kelas pada akhirnya adalah ini: siswa-siswi saya dan saya, bertatap muka, terlibat dalam sebuah proses pertukaran yang kuno dan kompleks yang disebut pendidikan. Teknik-teknik yang telah saya pelajari tidak hilang, tetapi teknik saja juga tidak cukup. Berhadapan dengan siswa-siswi saya, hanya satu sumber yang dapat saya kendalikan yaitu identitas saya, diri saya, kesadaran saya tentang "saya" yang mengajar - yang tanpanya saya tidak akan mengerti "Anda" yang belajar... 
pengajaran yang baik tidak dapat direduksi menjadi seperangkat teknik; pengajaran yang baik datang dari identitas dan integritas seorang guru)

Metode dan gaya pengajaran masing-masing merefleksikan ilmu (sains) dan seni pengajaran. Seorang guru harus menyadari bahwa pengajaran, di satu sisi, mencerminkan modernitas dan unsur ilmiah dari pendidikan tetapi, di lain sisi, tidak lepas dari sisi humanitas yang timbul serta keunikan-keunikan yang tidak dapat diprediksi secara ilmiah. Memahami dan mempraktikkan kombinasi sisi ilmiah dan sisi humanitas dalam mengajar bukanlah sesuatu yang mudah untuk dilakukan. Pemahaman ini menjadikan seorang pengajar sebagai instrumen yang lebih baik dalam proses belajar mengajar. Jarvis (2006) berargumen bahwa semakin seorang pengajar mengenal dirinya, semakin ia akan mengenal peserta didik yang diajarnya karena gaya mengajar sama pentingnya, bahkan mungkin lebih penting dari metode mengajar dalam proses belajar mengajar.

\subsubsection{Pengajar sebagai Pembicara Publik}

Seperti yang telah dijelaskan, sebagai sebuah teknik berbicara di depan publik, pendekatan public speaking yang berpusat pada audiens (audiencecentered approach) menjadi tren yang kerap muncul pada literatur-literatur tentang public speaking dewasa ini. Ini sejalan dengan pendekatan student-centered yang menyatakan Peneliti meyakini bahwa pendekatan yang berfokus pada kepentingan audiens adalah jalan terbaik untuk mencapai public speech yang baik. Dalam konteks pengajaran, mengambil pendekatan demikian berdampak pada bagaimana guru sebagai seorang pembicara publik menjalankan fungsi komunikasinya kepada siswa sebagai audiensnya.

Metode atau teknik public speaking pada seorang guru dimulai dari pengetahuan bahwa ketika fungsi dalam berbicara di depan siswa sebagai seorang pembicara publik sangat berbeda dengan proses komunikasi interpersonal ataupun proses komunikasi kelompok. Hasling (2006) menjelaskan bahwa karakteristik spesifik yang hanya dimiliki oleh public speaking bila dibandingkan dengan komunikasi pada level lain terletak pada empat faktor yakni struktur, tujuan, postur tubuh, dan motivasi dalam berkomunikasi.

Seorang guru perlu menyusun perencanaan dalam bentuk struktur yang sistematis tentang apa yang akan ia sampaikan pada siswanya. Dalam mempraktikkan public speaking, seorang guru perlu harus menciptakan sebuah kerangka yang mengorganisasikan konten yang akan ia sampaikan. Ia harus merencanakan konten serta urut-urutan apa yang akan ia sampaikan di dalam kelas. Ia juga harus mempersiapkan bagaimana membuka presentasinya, bagaimana menyampaikan inti materinya dan bagaimana serta apa yang akan disampaikan untuk menyimpulkan keseluruhan konten yang telah ia sampaikan. Pada saat berkomunikasi kepada siswanya, sangatlah penting bagi guru untuk berusaha berfokus pada satu tema sentral dan tidak terpancing untuk berbicara di luar topik karena akan menjadi pengalih perhatian yang dapat menyebabkan siswa tidak fokus.

Karakteristik kedua yang perlu dirumuskan dan dipertahankan oleh guru pada saat mengajar adalah tujuan berbicara di depan kelas. Setelah tujuan tersebut dirumuskan maka guru sebagai pembicara perlu mempertahankan konsistensi dalam berkomunikasi di mana tujuan penyampaian pesan menempati posisi terutama dalam proses penyampaian pesan. Pada seorang guru sedang berbicara untuk mempertahankan suatu argumen, ia harus konsisten dalam alur argumentasinya meskipun ia menemukan tandatanda keberatan dari audiens. Tentu saja penting baginya untuk bersikap terbuka pada pertanyaan maupun komentar dari audiens. Tetapi penting bagi guru, sebagai seorang pembicara publik, untuk menjawab pertanyaan dan komentar siswa dengan menjelaskan alasan dan tujuan mengapa materi tersebut disampaikan dengan cara yang dapat dimengerti oleh siswa.

Di sinilah kreativitas guru dalam berimprovisasi dapat dilakukan. Pembicara tidak dapat serta merta mengubah tujuannya pada saat ia sedang berbicara di depan publik. Strategi untuk menggunakan konten untuk mencapai tujuan presentasi harus disiapkan sebelum proses komunikasi berlangsung, bukan pada saat berpresentasi. Pada komunikasi interpersonal, seringkali komunikator dan komunikan spontan mengubah arah pembicaraan dan ini dapat terjadi berulangulang. Pada seorang pembicara publik, ini tidak boleh terjadi karena penting baginya untuk memegang kendali atas proses komunikasi yang sedang berlangsung.

Karakteristik ketiga yang perlu diperhatikan oleh seorang guru dalam berbicara di depan siswanya adalah postur tubuh. Dalam melakukan public speaking, pada umumnya seorang pembicara berdiri. Sungguh sangat jarang bila seorang pembicara publik 
yang efektif berbicara sambil duduk, apalagi bila jumlah audiens besar dan ruangan yang ditempati luas. Ini terkait dengan syarat utama seorang pembicara publik pada saat melakukan presentasi, yakni bahwa ia harus menjadi pusat perhatian. Guru harus membangun kondisi di mana perhatian murid tidak mudah teralihkan dari fokus pembelajaran yang sedang disampaikan. Berdiri adalah sebuah pesan non verbal yang menyatakan bahwa si pembicara menguasai podium (atau panggung) dan berharap agar audiens memperhatikan dan mendengarkannya.

Hasling (2006) mencatat bahwa pembicara dalam posisi duduk berpotensi memberi isyarat non-verbal bahwa ia tidak perlu diperhatikan dan bahwa audiens dapat berbicara satu dengan yang lain. Oleh karena itu postur tubuh guru pada saat berbicara sangat penting untuk menentukan apakah ia akan diperhatikan dan proses komunikasi publik dengan siswa berlangsung atau pembicara tidak diperhatikan dan proses komunikasi dalam belajar-mengajar mengalami kegagalan.

Karakteristik keempat adalah motivasi. Ini adalah perbedaan terpenting antara public speaking dengan komunikasi interpersonal. Percakapan dengan teman, misalnya, terjadi karena kedua orang komunikator/ komunikan menikmati pengalaman tersebut dan keduanya mendapatkan manfaat dari proses komunikasi yang terjadi. Ini artinya dalam komunikasi interpersonal kepentingan berkomunikasi adalah untuk komunikator sendiri. Sebaliknya, dalam komunikasi publik, motivasi utama dalam berkomunikasi adalah untuk kepentingan audiens. Seorang pembicara publik tidak berdiri di depan audiens hanya karena ingin memenuhi keinginannya untuk berbicara. Demikian pula seorang guru tidak mengajar di depan kelas hanya karena ia ingin bercerita. Motivasi berbicara pada komunikator adalah untuk kepentingan audiens. Karena itu penting bagi guru sebagai pembicara publik untuk berupaya menggali pengetahuan sebanyak mungkin tentang bidang yang sedang ia bicarakan. Lebih penting lagi adalah ia perlu tahu bagaimana menyampaikan informasi yang berguna bagi siswa sebagai komunikannya. Ia perlu membicarakan sesuatu yang relevan dengan kehidupan mereka.

Ketidakpedulian pembicara terhadap apa yang dianggap penting oleh audiensnya dapat mengakibatkan dampak yang fatal pada proses komunikasi yang terjadi. Dalam berkomunikasi, guru harus dapat mempertahankan perhatian siswanya sehingga siswa mengeluarkan umpan balik yang positif dan alur komunikasi dapat terus berlangsung. Pada saat guru gagal mempertahankan motivasi berkomunikasi untuk kepentingan audiensnya, maka siswa tidak akan tertarik untuk mendengarkan. Terkait dengan hal tersebut, Larry King, seorang pembicara publik ulung, memiliki dua kunci dalam berbicara di depan publik yang juga sangat berguna sebagai pegangan bagi guru sebagai pembicara, yaitu (1) Audiens Anda akan menjadi bosan kalau mereka tahu lebih banyak daripada Anda dan (2) Jika Anda tidak merasa yakin dengan topik yang dibicarakan, Anda bisa menjadi tidak yakin pula dalam sikap Anda (King \& Gillbert, 2004, p. 119).

Selanjutnya, Hasling (2006) juga menjelaskan bahwa seorang pembicara publik, sebuah citra diri (self image) perlu dibentuk. Aspek pertama dalam membentuk citra diri adalah sikap (attitude) terhadap public speaking. Sikap didefinisikan sebagai kecondongan atau tendensi seseorang terhadap sesuatu. Sikap yang positif berarti ia condong setuju terhadap sesuatu sementara sikap yang negatif mengisyaratkan ketidaksetujuan terhadap sesuatu. Sikap adalah aspek yang tidak dapat dipelajari karena sikap terbentuk selama kurun waktu yang lama. Oleh karena itu, seorang guru yang pernah mengalami pengalaman buruk berbicara di depan publik kemungkinan besar akan mengembangkan sikap yang negatif terhadap public speaking. Seorang guru yang terlibat dalam public speaking dengan frekuensi yang tinggi, harus mengevaluasi sikapnya terhadap proses berbicara di depan publik dan menemukan alasan mengapa ia memiliki sikap demikian dengan berkaca dari pengalaman lampaunya.

Selain sikap, persepsi seorang pembicara terhadap dirinya sendiri adalah faktor penting dalam menentukan karakternya sebagai seorang public speaker. Dalam konteks pengajaran, apabila seorang guru memiliki keyakinan terhadap dirinya bahwa ia dapat menjadi seorang public speaker yang baik, maka hal tesrebut akan tercermin dari caranya berbicara dan tampil di depan publik.

\section{KESIMPULAN}

Pemahaman terhadap aspek komunikasi dalam konteks pengajaran dapat memperkaya sekaligus mendukung dan mengembangkan teori dan praktik pengajaran. Dengan melakukan studi pustaka, penelitian ini memetakan dua konsep penting dalam public speaking dalam konteks pengajaran, yakni siswa sebagai audience dan guru sebagai speaker.

Menggunakan perspektif yang berpusat pada audiens, siswa dipandang sebagai komponen yang paling 
penting di dalam public speaking. Seorang guru sebagai speaker benar-benar harus mengenali siapa siwa yang akan dihadapinya sehingga materi dapat diterima dengan baik. Pendekatan ini sangat sesuai diterapkan dalam konteks pembelajaran di Indonesia mengingat saat ini sedang terus digalakkan sistem pendidikan nasional yang berpusat pada siswa.

Praktik mengajar dipandang sebagai sebuah metode sekaligus sebagai sebuah seni yang humanistic; demikian pula public speaking. Penelitian ini menemukan bahwa public speaking penting dikuasai oleh seorang guru dalam berbicara pada siswanya. Tetapi pada akhirnya, karakter guru dan pengenalannya tentang diri sendiri sebagai seorang pengajar dan seorang pembicara sama pentingnya untuk menentukan keberhasilannya dalam mengenali audiensnya dan mempraktikkan public speaking.

Untuk penelitian selanjutnya, dapat dilakukan eksplorasi teori dan praktik public speaking dalam konteks lain, seperti pemerintahan, hiburan, perdagangan, dll. Sehingga pemahaman mengenai public speaking dan praktiknya dapat dilakukan secara kontekstual. Selain itu, karena kedua peneliti yang melakukan riset ini berlatarbelakang Ilmu Komunikasi, peneliti menyadari bahwa ada keterbatasan dalam hal pendalaman konsep dan teori dari sisi pendidikan dan pembelajaran. Oleh karena itu, peneliti mengundang pembaca penelitian ini, khususnya yang berlatarbelakang ilmu pendidikan (andragogi maupun pedagogi) untuk mengerjakan sebuah riset akademik interdisipliner tentang public speaking dan pengajaran.

\section{DAFTAR REFERENSI}

Beebe, S., Beebe, J. Public Speaking: An AudienceCentered Approach ( $7^{\text {th }}$ ed.). USA: Pearson.

Brooksfield, S. (2006). The Skillfull Teacher: On Techniques, Trust, and Responsiveness in the Classroom ( $2^{\text {nd }} e d$.). San Fransisco: Josey-Bass.

Clark, R. A., \& Jones, D. (2001). A comparison of traditional and online formats in a public speaking course. Communication Education, 50(2), 109-124. Retrieved from http://search. proquest.com/docview/214121525?accountid=8 624.

Dananjaya, U. (2010). Media Pembelajaran Aktif. Bandung: Nuansa.
DeVito, J. (2009). The Essential Elements of Public Speaking. USA: Pearson.

Hall, S. (1980). Encoding/Decoding. In Chandler, (n.d.). Semiotics for Beginners. Retrieved from www.aber.ac.uk/media/Documents/S4B/sem08 c.html.

Hasling, J. (2006). The Audience, the Message, the Speaker $\left(7^{\text {th }}\right.$ ed.). New York: McGraw Hill.

Herrick, J. (2008). The History and Theory of Rhetoric: An Introduction ( $4^{\text {th }} e d$.). Allyn \& Bacon.

Hill, A., Watson, J., Rivers, D., Joyce, M. Key Themes in Interpersonal Communication: Culture, Identities and Performance. New York: McGraw-Hill Open University Press.

Jarvis, P. (2006). The Theory and Practice of Teaching $\left(2^{\text {nd }} e d\right)$. London and New York: Routledge.

King, L., Gilbert, Bill. (2004). Seni Berbicara kepada Siapa Saja, Kapan Saja, di Mana Saja: Rahasiarahasia Komunikasi yang Baik $\left(2^{\text {nd }} e d\right.$.). Jakarta: Gramedia Pustaka Utama.

Kusuma, D., Hermana, D., Supardan, D., Undang, G. (2010). Contextual Teaching and Learning: Sebuah Panduan Awal dalam Pengembangan $P B M$. Yogyakarta: Rahayasa

Littlejohn, S. (2002). Theories of Human Соттиnication. USA: Wadsworth

Lindlof, T., Taylor, B. (2002). Qualitative Cоттиnication Research Methods ( $2^{\text {nd }} e d$ ). USA: Sage Publications, Inc.

MacNaughton, G., Williams, G. (2004). Teaching Young Children: Choices in Theory and Practice. Australia: Pearson Education.

Patton, B. (1983). Responsible Public Speaking. Illinois: Scott, Foresman.

Pan, L., \& Yan, P. (2010). Primary study on public speaking in chinese korean education. Asian Social Science, 6(5), 70-75. Retrieved from http://search.proquest.com/docview/821814071? accountid $=8624$

Rivera, M. (2011, May 02). Public speaking helps latino students prepare for higher education. The Hispanic Outlook in Higher Education, 21, 64. Retrieved from http://search.proquest.com/ docview/867683815?accountid=8624.

Soenarjo, D., Rajiyem. (2005). Public Speaking. Jakarta: Universitas Terbuka.

Verderber, R., Verderber, K., Sellnow, D. (2008). The Challenge of Effective Speaking. USA: Thomson Wadsworth. 